\title{
New records of Grammicolepis brachiusculus Poey, 1873 (Zeiformes: Grammicolepididae) in Brazilian waters, with a key to Western Atlantic species of Grammicolepididae
}

\author{
Alfredo Carvalho-Filho ${ }^{1,4}$, Guy Marcovaldi ${ }^{2}$, Flavia Almeida Ribeiro ${ }^{2}$, Maria Isabel G. Paiva ${ }^{2}$ and \\ Cláudio L. S. Sampaio ${ }^{3}$ \\ 1 Fish-Bizz Ltda. Rua Maria Garcez, 39. CEP 05424-070. São Paulo, SP, Brazil. \\ 2 Projeto Tamar-ICMBio. Avenida do Farol Garcia D’Ávila, s/n, Praia do Forte. CEP 48280-000. Mata de São João, BA, Brazil. \\ 3 Universidade Federal de Alagoas, Unidade de Ensino Penedo. Av. Beira Rio s/n, Centro Histórico. CEP 57200-000. Penedo, AL, Brazil. \\ 4 Corresponding author. E-mail: alfie@telnet.com.br
}

\begin{abstract}
Grammicolepis brachiusculus, commonly known as Thorny tinselfish, was previously cited from Brazilian waters, but not thoroughly documented. Here we report about a new record of this species, based on three voucher specimens, 169.2-196.3 mm SL, collected off Bahia, Brazil. This report extends the range of the species southwards for a distance of about 3,500 kilometers along the South American coastline. Given its rarity, an updated diagnosis of the species, and an identification key to the Western Atlantic species of Grammicolepididae, are provided.
\end{abstract}

Grammicolepididae contains only three monotypic genera with meso-benthopelagic species (Tyler et al. 2003; Nelson 2006). The inclusion of this family in the Zeioidei (Zeiformes) and the inclusion of the Pacific Macrurocyttus acanthopodus Fowler, 1933 in Grammicolepididae are discussed by Tyler et al. (2003). Morphological/ morphometric differences among the species of Zeioidei are also provided by Heemstra (2002). Only one species of Grammicolepididae is reported from Brazilian waters: Xenolepidichthys dalgleishi Gilchrist, 1922 (Figueiredo and Menezes 1980; Figueiredo et al. 2002; Menezes 2003; Bernardes et al. 2005). Grammicolepis brachiusculus Poey, 1873 is the other Western Atlantic species of the family previously known to occur between Georges Bank off Canada to the Gulf of Mexico and northern South America, off Venezuela and Suriname (Poey 1883; Jordan and Evermann 1896; Shimizu 1983; Karrer and Heemstra 1986; Quéro 1986; Cervigón 1996; McEachran and Fechhelm 1998; Heemstra 2002; Moore and DeWitt 2002; Tyler et al. 2003; Ditty 2006). Despite previously cited by Costa et al. (2007), the occurrence of G. brachiusculus in Brazilian waters is herein first documented. In addition, a brief re-description of $G$. brachiusculus based on the three specimens from Brazil and on information from the literature is provided.

Measurements of the specimens were taken with a caliper to tenths of millimeters $(\mathrm{mm})$. Institutional abbreviations follow Sabaj Pérez (2010). The key to Western Atlantic species of Grammicolepididae is based on information from the literature and on the following specimens examined: Grammicolepis brachiusculus: TAMAR 036 (3 pre-juveniles, 169.2-196.3 mm SL), 12³9'91" S, $37^{\circ} 54^{\prime} 30^{\prime \prime} \mathrm{W}$, at about $500 \mathrm{~m}$ depth, off Praia do Forte, Mata de São João, Bahia, Brazil (from stomach contents of a large Ruvettus pretiosus Cocco, 1833), collected by G. Marcovaldi on 26 October 2007; Xenolepidichthys dalgleishi: MZUSP 80422 (4 juveniles, 34.2-52.4 mm SL), 27¹4'04" S, $46^{\circ}$
46'53" W, at 250 m depth, off Santa Catarina, Brazil, RV Atlântico Sul, REVIZEE SCORE Sul, station PE06, collected on 16 October 1999; AZUSC 2990 (4, 130.0-190.4 mm

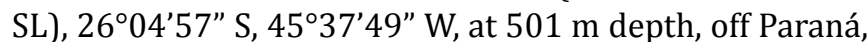
Brazil, RV Soloncy Moura, collected on $1^{\text {st }}$. August 2003.

\section{Grammicolepis brachiusculus Poey, 1873}

Thorny tinselfish, Palombeta-de-fundo

(Figures 1-2, Tables 1-2)

Synonyms: Vesposus egregious Jordan, 1921; Xenolepidichthys americanus Nichols and Firth, 1939; Daramattus americanus (Nichols and Firth, 1939); Daramattus armatus Smith, 1960; Daramattus barnardi Smith, 1968.

Diagnostic characters: Based on the specimens examined and on the literature (Poey 1883; Myers 1937; Shimizu 1983; Karrer and Heemstra 1986; Quéro 1986; Cervigón 1996; McEachran and Fechhelm 1998; González et al. 1999; Heemstra 2002; Moore and DeWitt 2002; Tyler et al. 2003; Pequeño and Matallanas 2004; Ditty 2006). Morphological data are presented in Tables 1 and 2. The species has three morphologically distinct phases, in addition to the larval stage: pre-juvenile, juvenile and adult. The depth of body, relative position of dorsal and anal fins origin, presence of scutes/spines on body and on the bases of dorsal and anal fins, and the length of the anterior spines of these fins, vary strongly with age. The body is strongly compressed, rather high in pre-juveniles to oblong in adults, the greatest depth varying from at least 74.5\% (taken from a 94-mm SL specimen, Cervigón 1996), to about $43 \%$ of standard length; mouth small, terminal, and almost vertical; snout short; eye large; dorsal and anal fin-bases long, with spiny scutes in prejuveniles (29-34 at base of dorsal fin and 27-35 at base of anal fin), absent in adults; dorsal and anal fin with anterior 
elements prolonged in pre-juveniles, much short in adults; in pre-juveniles and juveniles the first anal fin spine may surpass the caudal fin base, but often is broken and short in specimens deposited in fish collections; anal fin origin almost opposite to dorsal fin origin in pre-juveniles, but it is rather posterior to dorsal fin origin in adults; first spine of dorsal fin reduced, often not visible externally; scales small, vertically elongate; sides of body and caudal peduncle with 10-13 flat spiny scutes, absent in adults; caudal fin usually emarginated in pre-juveniles, central rays very elongate in juveniles but emarginated in large adults. Principal caudal-fin rays 15 , with one procurrent ray in dorsal and one in the ventral portion of the caudalfin; pelvic fin with one spine and 6-7 rays; branchiostegal rays 7; vertebrae 43-46. Metamorphosis from pre-juvenile to juvenile occurs between 25 to $30 \mathrm{~cm}$ SL. Pre-juveniles and juveniles are blue-silvery to brassy with irregular dark blotches or bars on body, anal, and caudal fins; the spiny scutes may be very dark in color, suggesting black spots from distance. Adults are dull silvery to partial (head and/or belly) violet-blue, eventually with faint darker or lighter marks on body and caudal fin; iris golden to silvery and often reddish due to blood perfusion. Live specimens recorded from deep waters might display an overall blue color due to the blue light produced by submersibles (Kenneth Sulak, pers. comm.). Maximum SL reported 470 $\mathrm{mm}$, from Poey's original description.

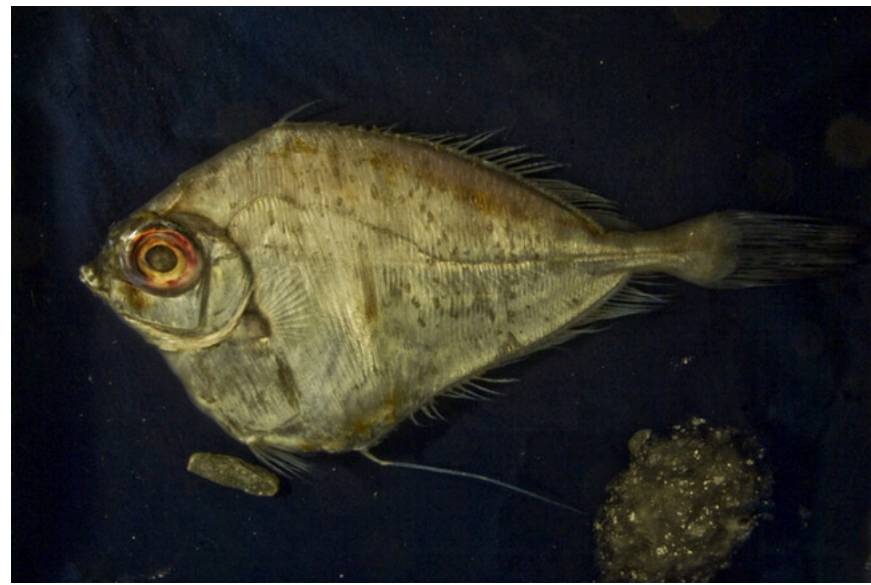

FIGURE 1. Grammicolepis brachiusculus, TAMAR 036, $196.3 \mathrm{~mm} \mathrm{SL}$, off Praia do Forte, Mata de São João, Bahia, Brazil. Pedro Cordeiro.

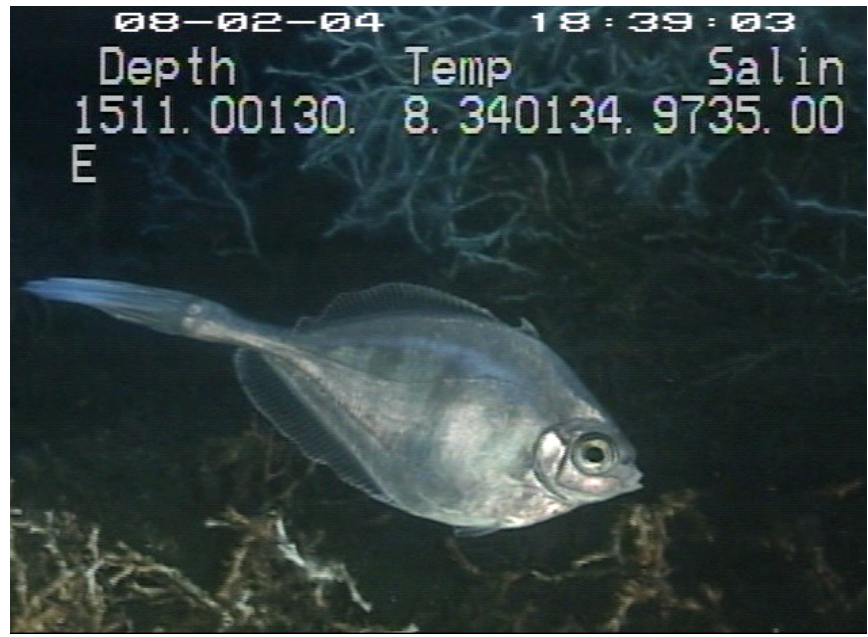

FiguRE 2. Grammicolepis brachiusculus, alive in deep water at Vioska Knoll shipwreck, south of Mobile, Alabama, Northern Gulf of Mexico, Station JSL 4751, $1510 \mathrm{ft}$ deep. Kenneth Sulak.
Distribution: Eastern Atlantic: off Ireland and Scotland south to Spain, Canary Islands, Ascension Island, and northern Africa southwards to Durban, South Africa. Indian Ocean: off Madagascar and Mozambique. Indo-Pacific: from Western Australia northwards to Japan, Hawaii and off Chile (Pequeño and Matallanas 2004). Western Atlantic: from Georges Bank through the Caribbean to Bahia, northeastern Brazil (Figure 5). The previously known southernmost record of the species in the Western Atlantic was Suriname (Shimizu 1983). In this study, the range of the species is extended southwards for a distance of about 3,500 kilometers.

Previous records from Brazilian waters: Costa et al. (2007) reported on the collection of one specimen of $G$. brachiusculus in the Brazilian central east coast (Bahia, Espírito Santo and north of Rio de Janeiro (11-22 ${ }^{\circ} \mathrm{S}$ ), collected by RV Thalassa (IFREMER) between May and July, 2000. The specimen was listed by Costa et al. (2007) among fishes collected in the region during the REVIZEE Program; morphological and distributional data on the

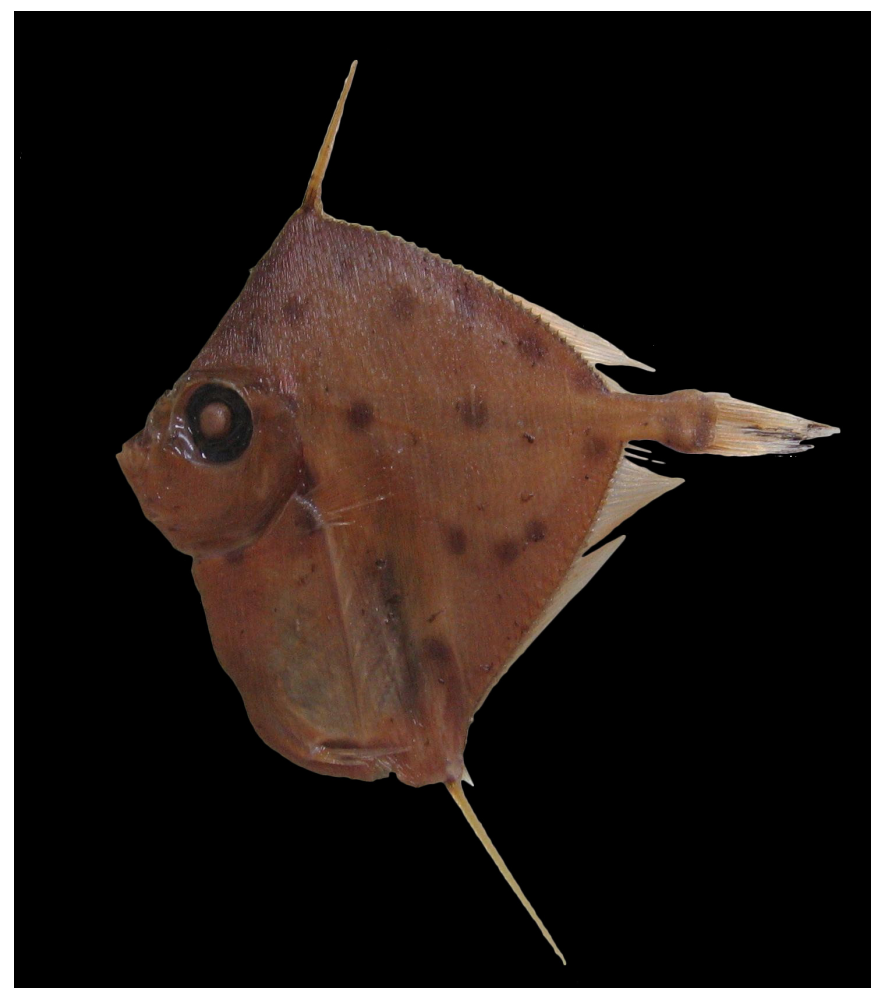

FIGURE 3. Xenolepidichthys dalgleishi, MZUSP 80422, juvenile, $48.3 \mathrm{~mm}$ SL.

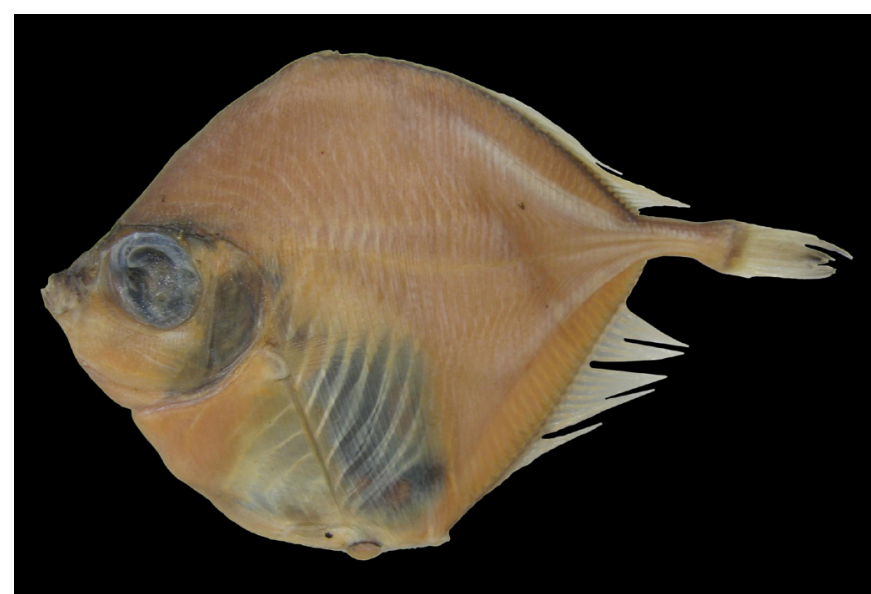

Figure 4. Xenolepidichthys dalgleishi, AZUSC 2990, female, 139.0 mm SL. 


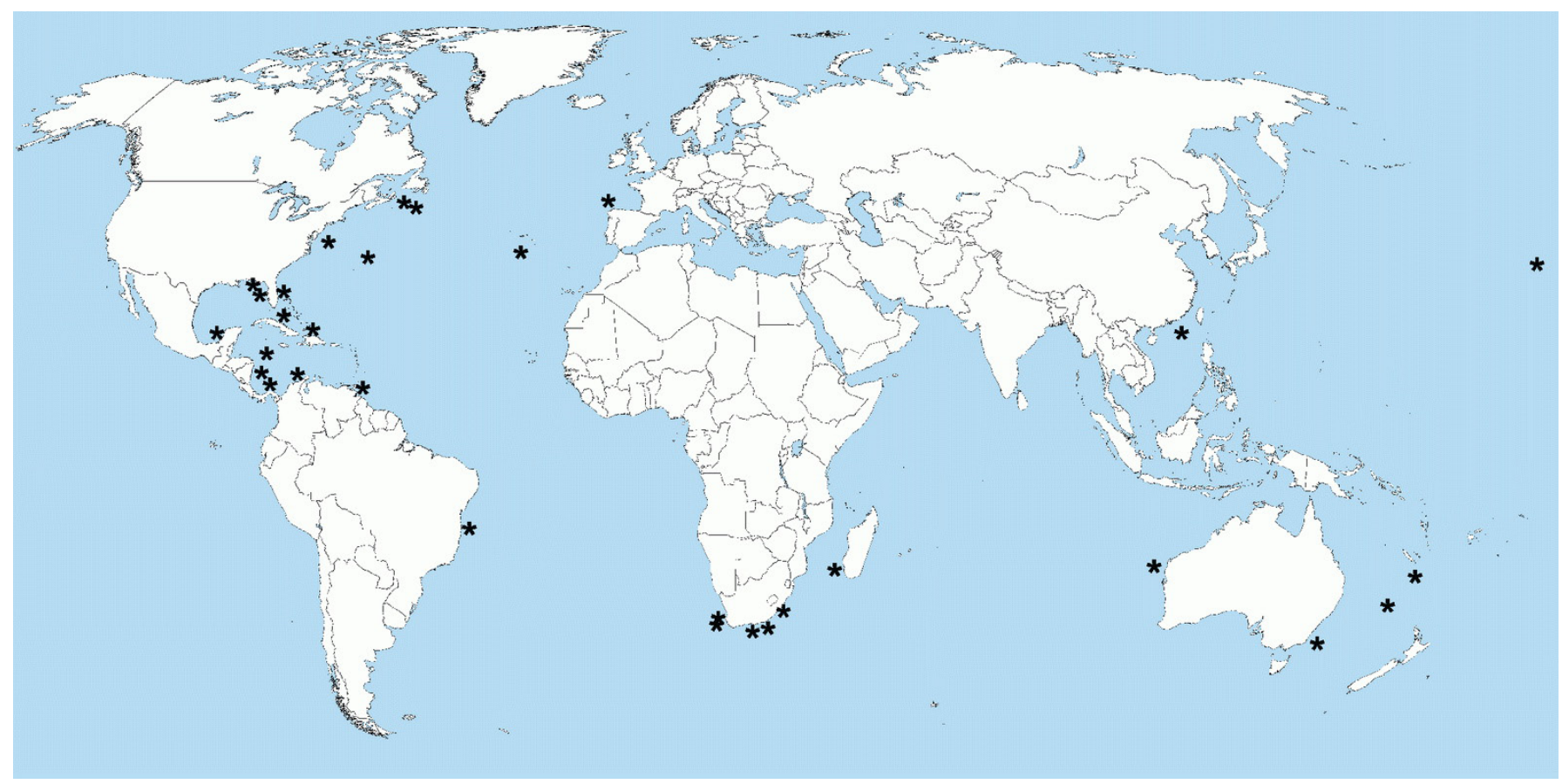

FigURE 5. Distribution of Grammicolepis brachiusculus. Modified from OBIS (http://www.obis.org.au/cgi-bin/cs_map.pl).

TABLE 1. Meristic data of Grammicolepis brachiusculus. Abbreviation: NA, not available.

\begin{tabular}{|c|c|c|c|c|c|c|c|c|}
\hline COUNTS & $\begin{array}{c}\text { Poey } \\
\text { (1883) }\end{array}$ & $\begin{array}{c}\text { Myers } \\
\text { (1937) }\end{array}$ & $\begin{array}{c}\text { Shimizu } \\
\text { (1983) }\end{array}$ & $\begin{array}{c}\text { Karrer and } \\
\text { Heemstra } \\
(1986)^{*}\end{array}$ & $\begin{array}{c}\text { Cervigón } \\
\text { (1996) }\end{array}$ & $\begin{array}{c}\text { González } \\
\text { et al. } \\
\text { (1999) }\end{array}$ & $\begin{array}{c}\text { Pequeño and } \\
\text { Matallanas } \\
(2004)\end{array}$ & $\begin{array}{c}\text { PRESENT } \\
\text { STUDY }\end{array}$ \\
\hline N. of Specimens & 1 & 5 & 1 & NA & 3 & 2 & 1 & 3 \\
\hline $\mathrm{SL}(\mathrm{mm})$ & 470 & $73-230$ & 218 & NA & $94-230$ & $418-424$ & 270 & $169-196$ \\
\hline Dorsal fin spines & VI & VI-VII & VII & VI-VII & $\mathrm{V}^{* *}$ & $\mathrm{~V}^{* *}$ & VI & VI \\
\hline Dorsal fin rays & 34 & $28-35$ & 32 & $32-34$ & $28-33$ & $33-34$ & 34 & 33 \\
\hline Anal fin spines & II & II & II & II & II & II & II & II \\
\hline Anal fin rays & 33 & $28-36$ & 34 & $33-35$ & $28-35$ & 34 & 37 & 33 \\
\hline Pectoral fin rays & 15 & $14-16$ & 15 & $14-15$ & 14-15 & 15 & NA & 14 \\
\hline Gill rakers & NA & NA & NA & $1-2+12$ & $1-2+14-15$ & $14-15$ & NA & $1-2+13-15$ \\
\hline Lateral line scales & NA & NA & NA & NA & NA & $120-122$ & NA & 115-119 \\
\hline
\end{tabular}

* data from several previous papers included.

** first spine of dorsal fin minute, often not visible externally.

TABLE 2. Selected measurements (in \% of SL) of Grammicolepis brachiusculus. Abbreviations: NA, not available; P, Pre-juvenile; J: Juvenile; A, adult.

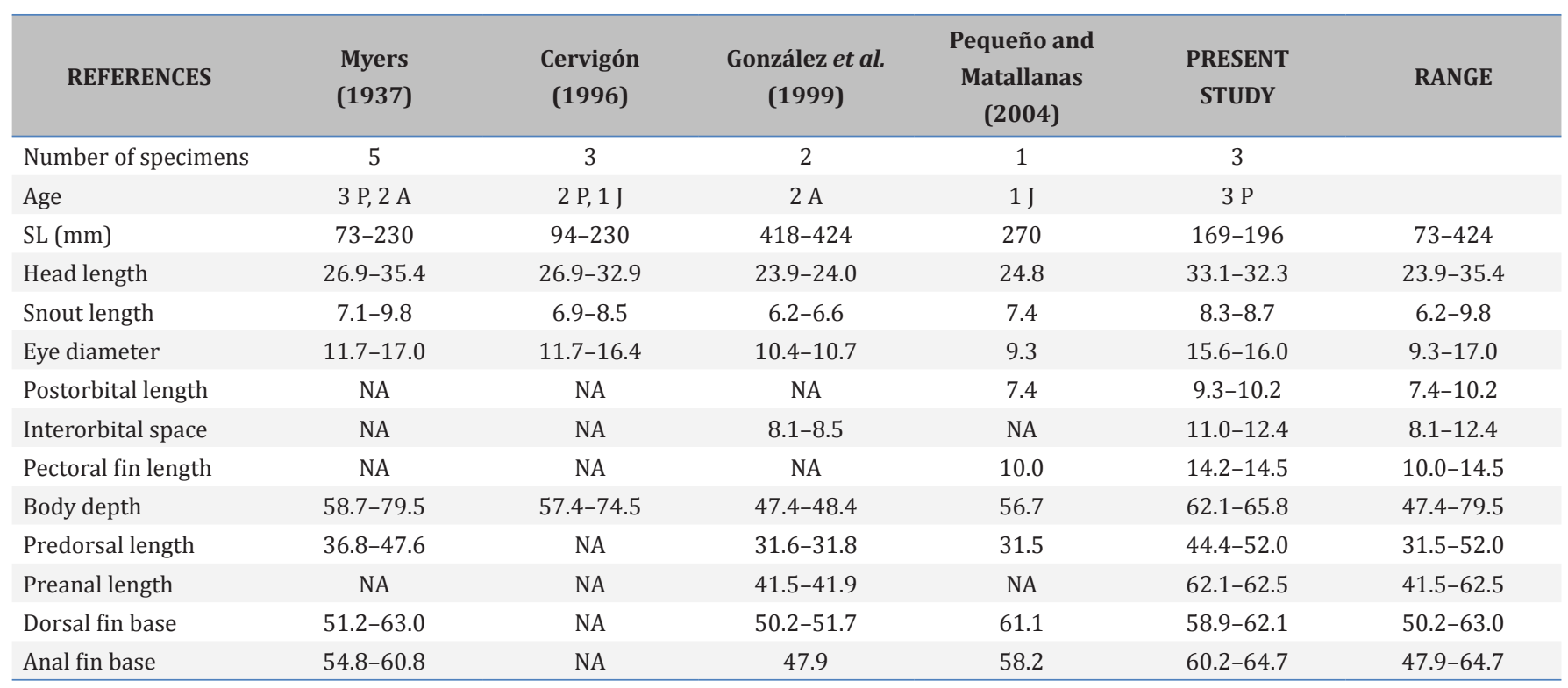


specimen collected were not provided. As far as we know, this specimen was not deposited in fish collection.

Biological data: Stomach contents of the three specimens were analyzed and we found just a mass of digested animal remains, impossible to identify. According to Kenneth Sulak (pers. comm., after watching the fish behavior displayed by video feeding), "the fish hovers very slowly maneuvering among the coral branches [... of Lophelia]. I believe it feeds on the small snow white alpheid shrimps that live on Lophelia."

\section{Key to the Western Atlantic species of Grammicolepididae \\ [Modified from Myers (1937), Cervigón (1996), Heemstra (2002), and Tyler et al. (2003)]}

1a. Dorsal fin elements VI-VII, 28-35 (usually 32-34); anal fin elements II, 28-37 (usually 33-35); pectoral fin rays 14-15 (sometimes 16); edge of elongate vertical scales serrated; pre-juveniles and juveniles with about 10 horizontal scale crests on body and caudal peduncle, absent in adults; 34-36 spiny protuberances along dorsalfin base. . Grammicolepis brachiusculus (Figures 1-2)

1b. Dorsal fin elements V-VI, 27-30; anal fin elements II, 27-29; pectoral fin rays 14-15; edge of elongate vertical scales relatively smooth; no scale crests on body at any age; about 29 spiny protuberances along dorsal-fin base. Xenolepidichthys dalgleishi (Figures 3-4)

ACKNOWLEDGMENTS: The authors thank Kenneth Sulak (Southeastern Ecological Science Center, USA), Fabio Di Dario, Paulo Costa, Osmar Luiz Jr., and Ivan Sazima, for their extremely valuable review, comments and suggestions; Matheus Rotundo (Universidade Santa Cecilia, Brazil), for valuable information; Domingos (Atoa) Dantas de Carvalho, Renildo Dantas de Carvalho and Adriano de Jesus Santos, captain and crew of the TAMAR vessel, for their help at sea; Pedro Mariano Monteiro de Barros Cordeiro (TAMAR), for his superb pictures; Sergio de Azevedo Vinhes and Gustavo Rodamilans de Macedo (both from TAMAR), for their help in the field; Neca Marcovaldi and Eliane Pinto for their support. We also thank the anonymous referees for their suggestions and critical comments on the manuscript.

\section{LITERATURE CITED}

Bernardes, R.A., J.L. Figueiredo, A.R. Rodrigues, L.G. Fischer, C.M. Vooren, M. Haimovici, and C.L.D.B. Rossi-Wongtschowski. 2005. Peixes da Zona Econômica Exclusiva da região Sudeste-Sul do Brasil: levantamento com armadilhas, pargueiras e rede de arrasto de fundo. São Paulo: Edusp. 295 p.

Cervigón, F. 1991. Los peces marinos de Venezuela, Vol. I. Caracas: Fundación Científica Los Roques. 423 p.

Cervigón, F. 1996. Los peces marinos de Venezuela, Vol. IV, Apéndice, 173175. Caracas: Fundación Científica Los Roques. 255 p.

Costa, P.A.S., A.C. Braga, M.R.S. Melo, G.W.A. Nunan, A.S. Martins and G. Olavo. 2007. Assembléias de teleósteos demersais no talude da costa central brasileira; p. 87-107. In P.A.S. Costa, G. Olavo and A.S. Martins (ed.). Biodiversidade da fauna marinha profunda na costa central brasileira. Documentos REVIZEE, Score Central. Série Livros, n. 24. Rio de Janeiro: Museu Nacional.
Ditty, J.G. 2006. Order Zeiformes: Families Parazenidae, Zeniontidae, Zeidae, Oreosomatidae and Grammicolepidae; p. 1109-1119. In W.J. Richards (ed.). Early stages of Atlantic fishes, an identification guide for the Western Central North Atlantic. Vol. I. Boca Raton: Taylor and Francis.

Figueiredo, J.L., A.P. Santos, N. Yamaguti, R.A. Bernardes and C.L.D.B. Rossi-Wongtschowski. 2002. Peixes da Zona Econômica Exclusiva da região Sudeste-Sul do Brasil: levantamento com rede de meia água. São Paulo: Edusp. 242 p.

González, J.A., V. Rico and J.L. Santana. 2000. Capture of Grammicolepis brachiusculus Poey, 1873 (Grammicolepididae) off the Canary Islands. Scientia Marina 64(1): 107-109.

Heemstra, P.C. 2002. Grammicolepidae; p. 1214-1216. In K.E. Carpenter (ed.). The living marine resources of the Western Central Atlantic. Volume 2, Bony fishes part 1 (Acipenseridae to Grammatidae). Rome: FAO.

Jordan, D.S. and B.W. Evermann. 1896. The fishes of North and Middle America: a descriptive catalogue of the species of fish-like vertebrates found in the waters of North America, north of the Isthmus of Panama. Part I. Bulletin of the United States National Museum 47: 1-1240.

Karrer, C. and P.C. Heemstra. 1991. Grammicolepididae; p. 440-441. In M.M. Smith and P.C. Heemstra (ed.). Smith's sea fishes, 1st. ed. Johannesburg: Southern Book Publishers.

McEachran, J.D. and J.D. Fechhelm. 1998. Fishes of the Gulf of Mexico, Volume 1, Myxiniformes to Gasterosteiformes. Austin: University of Texas Press. $1004 \mathrm{p}$

Menezes, N.A. 2003. Grammicolepididae; p. 70. In N.A. Menezes, P.A. Buckup, J.L. Figueiredo and R.L. Moura (ed.). Catálogo das espécies de peixes marinhos do Brasil. São Paulo: Museu de Zoologia da Universidade de São Paulo.

Moore, J.A. and H.H. DeWitt. 2002. Grammicolepididae. In B.B. Collette and G. Klein-MacPhee (ed.). Bigelow and Schroeder's fishes of the Gulf of Maine, $3^{\text {rd }}$ ed. Washington: Smithsonian Institution Press. 748 p.

Myers, G.S. 1937. The deep-sea zeomorph fishes of the family Grammicolepidae. Proceedings of the United States National Museum 84(3008): 145-156.

Nelson, J.S. 2006. Fishes of the world. $4^{\text {th }}$ ed. Hoboken: John Wiley and Sons, Inc., $601 \mathrm{p}$.

Nion, H., C. Rios and P. Meneses. 2002. Peces del Uruguay: lista sistemática y nombres comunes. Montevideo: DINARA, Infopesca. 105 p.

OBIS. 2011. Ocean Biogeography Information. Version January 13, 2011 Electronic database accessible at http://www.iobis.org. Captured on September 2, 2011.

Pequeño, G. and J. Matallanas. 2004. First record of the family Grammicolepididae, with Grammicolepis brachiusculus Poey, 1873, in the Southeastern Pacific Ocean (Osteichthyes: Zeiformes). Journal of Ichthyology 44(suppl. 1): 145-149.

Poey, F. 1883. Ictiología Cubana. Transcripción, conjunction y edición científica por Dario Guitart Manday (2000). Vol. I, Grammicolepididae; p. 426-428; Vol. III (Atlas): Lámina 279. La Habana: Imagen Contemporanea.

Quéro, J.-C. 1989. Grammicolepididae; p. 773-774. In P.J.P. Whitehead, M.-L. Bauchot, J.-C. Hureau, J. Nielsen and E. Tortonese (ed.). Fishes of the North-eastern Atlantic and the Mediterranean, Volume II. Paris: UNESCO.

Sabaj Pérez, M.H. (ed.). 2010. Standard symbolic codes for institutional resource collections in herpetology and ichthyology: an online reference. Version 1.5 (October 4, 2010). Electronic Database accessible at http://www.asih.org.

Shimizu, T. 1983. Grammicolepididae; p. 290-291. In T. Uyeno, K. Matsuura and E. Fujii (ed.). Fishes trawled off Suriname and French Guiana. Tokyo: Japan Marine Fishery Resource Research Center.

Tyler, J.C., B. O'Toole and R. Winterbottom. 2003. Phylogeny of the genera and families of zeiform fishes, with comments on their relationships with tetraodontiforms and caproids. Smithsonian Contributions to Zoology 618: 1-110.

RECEIVED: September 2011

ACCEPTED: February 2012

PuBlished ONLINE: August 2012

EDITORIAL RESPONSIBILITY: Michael Maia Mincarone 